Original Article

\title{
SYNTHESIS, BIOLOGICAL STUDY, DNA INTERACTION OF MANNICH BASE METAL COMPLEXES DERIVED FROM BENZAMIDE
}

\author{
SIVAKAMI SUDHASANKAR ${ }^{*}$ \\ ${ }^{1 *}$ Department of Chemistry, Faculty of Engineering and Technology, SRM Institute of Science and Technology, Kattankulathur 603203
}

Email: sivakamm@srmist.edu.in

Received: 04 Aug 2021, Revised and Accepted: 10 Oct 2021

\section{ABSTRACT}

Objective: Coordination compounds occur widely in nature and they comprise a large share of current inorganic research. The Mannich reaction is a classic method for the preparation of Mannich bases, namely, $\beta$ amino compounds, which are heterocyclic.

Methods: A novel Mannich base of N-((3,4-dimethoxyphenyl)(2,5-dioxopyrrolidin-1-yl) methyl)benzamide and its coordination complexes with transition metals $\mathrm{Mn}$ and Co have been synthesized and characterized by elemental analysis, molar conductance, magnetic susceptibility measurements, UV-Visible, IR, NMR, and Mass spectral studies.

Results: Based on the magnetic moment and UV-Visible spectral data, octahedral geometries were assigned for the metal complexes. The metal complexes were screened for antifungal activity.

Conclusion: the metal complexes have shown good activity than the ligand. The binding of selected metal complexes with calf thymus DNA was investigated. It is found that the cobalt (II) metal complex of the ligand showed efficient DNA binding ability.

Keywords: Coordination compounds, Mannich base, UV-Visible, Antifungal activity, DNA binding

(C) 2021 The Authors. Published by Innovare Academic Sciences Pvt Ltd. This is an open-access article under the CC BY license (https://creativecommons.org/licenses/by/4.0/) DOI: https://dx.doi.org/10.22159/ijcpr.2021v13i6.1917 Journal homepage: https://innovareacademics.in/journals/index.php/ijcpr

\section{INTRODUCTION}

Transition metals have an important role in medicinal biochemistry. Research has shown significant progress in the utilization of transition metal complexes as drugs to treat several diseases like carcinomas, lymphomas, infection control, anti-inflammatory, diabetes, and neurological disorders [1-4]. Manganese is an essential element involved in many chemical processes in the body, including the processing of cholesterol, carbohydrates, and protein. Iron compounds include hemoglobin which keeps our blood red. Iron atoms also help to join organic molecules, forming bactericides or bacteriostatic agents [5]. Cobalt contained in Vitamin B12 is important in protein formation and DNA regulation. Cobalt-60, a radioactive isotope, is used as a commercial source of high-energy radiation in medicine to destroy cancerous tissue. Cobalt-containing drugs are used as cyanide antidotes. Mannich bases of benzamide and succinimide are known to play a prominent role in medicinal chemistry. Despite the assets of available paper, it is found that they possess various pharmacological properties as hypnotic and tranquilizer activity, CNS depressant and cardiac stimulant, tumorinhibiting properties, and antibacterial activity [6-8]. Moreover, the presence of Mannich side chain increases the solubility and bioavailability of the drug molecule [9-11]. This work focuses on the synthesis of $\mathrm{Mn}$ (II) and $\mathrm{Co}(\mathrm{II})$ complexes with a new series of Mannich bases derived from succinimide, benzaldehyde, and benzamide.

\section{MATERIALS AND METHODS}

All the reagents and solvents used for the synthesis of ligand and the metal complexes were AR grade quality and have been utilized with no purification. Elemental analysis was performed using Carbo Erba 1108 analyzer and Coleman $\mathrm{N}$ analyzer and was found within $\pm 0.5 \%$. The molar conductivities of metal complexes were measured in approximately 10-3 M ethanol solution using a systronics direct reading digital conductivity meter-304 with dip-type conductivity cell. The IR spectra were recorded as $\mathrm{KBr}$ pellets on Perkin-Elmer 1000 unit instrument. Absorbance in the UV-Visible region was recorded in DMF solution using a UV-Visible spectrometer. The $1 \mathrm{H}$ and 13CNMR of the ligand were recorded in the Bruker instrument employing TMS as internal standard and DMSO-DMF as internal solvent. Magnetic susceptibility measurements at room temperature were made by using a Guoy magnetic balance. Anti-microbial screening of the test compounds was carried out using the Agar-well diffusion method.

Preparation of N-((3,4-dimethoxyphenyl)(2,5-dioxopyrrolidin1-yl) methyl)benzamide (NDB)

The new Mannich base N-((3,4-dimethoxyphenyl)(2,5dioxopyrrolidin-1-yl) methyl)benzamide (NDB)has been synthesized by the condensation of equimolar quantities of succinimide, dimethoxy benzaldehyde, and benzamide by the following method. $1 \mathrm{~g}(0.01 \mathrm{~mol})$ of succinimide and $0.48 \mathrm{~g}(0.01 \mathrm{~mol})$ of benzamide was dissolved in a small amount of distilled water and taken in a $100 \mathrm{ml}$ beaker. $1.67 \mathrm{~g}(0.01 \mathrm{~mol})$ of dimethoxy benzaldehyde dissolved in acetone was added dropwise to the beaker solution and stirred with a magnetic stirrer for one day. Then it is kept aside with occasional stirring for few days. After a week a solid product formed was filtered, washed with distilled water and dried in an air oven at $60{ }^{\circ} \mathrm{C}$, and recrystallized using ethanol and $\mathrm{CHCl}_{3}$ in 1:1 ratio (fig. 1).

\section{Synthesis of manganese sulphate complex of NDB}

To a salt solution of Manganese sulphate $(0.05 \mathrm{~g})$, ethanolic solution of the ligand NDB $(0.1 \mathrm{~g})$ was added slowly with stirring. The solution is stirred well in a hot late with a magnetic stirrer to get a clear solution. It is covered with aluminum foil and kept aside for 2 w. After slow evaporation of the solvent at $28{ }^{\circ} \mathrm{C}$, a dull white colored compound was obtained. It was filtered and dried in a vacuum (fig. 2).

\section{Synthesis of manganese chloride complex of NDB}

To a solution of Manganese chloride $(0.061 \mathrm{~g})$, ethanolic solution of the ligand NDB $(0.1 \mathrm{~g})$ was added slowly with stirring. After stirring for $4 \mathrm{~h}$, a clear solution was obtained. It is covered with aluminum foil and kept for a few days. A resulting dull-white solid was separated on evaporating the solution at room temperature. It is filtered and dried in a vacuum (fig. 2). 


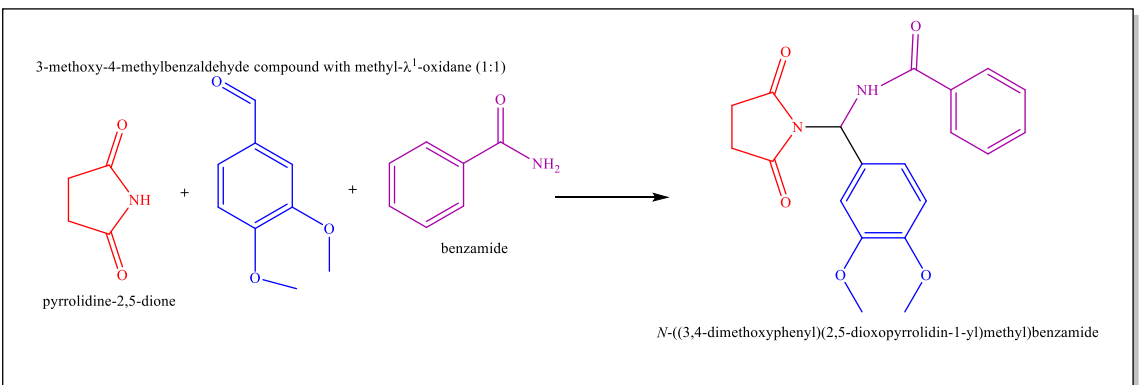

Fig. 1: Preparation of N-((3,4-dimethoxyphenyl) (2,5-dioxopyrrolidin-1-yl) methyl)benzamide (NDB)

\section{Synthesis of cobalt sulphate complex of NDB}

The cobalt sulphate complex of NDB was prepared by refluxing a solution of Cobalt sulphate $(0.08 \mathrm{~g})$ with an ethanolic solution of the ligand NDB $(0.1 \mathrm{~g})$ for 1 hour to obtain a clear solution. After keeping aside the resultant solution for $2 \mathrm{w}$, blue crystals of the metal complex were separated on evaporating the solution at room temperature. It is filtered and dried in a vacuum (fig. 2).

\section{Synthesis of cobalt chloride complex of NDB}

The cobalt chloride complex of NDB was prepared by refluxing a hot suspension of cobalt chloride $(0.735 \mathrm{~g})$ with an ethanolic solution of the ligand $(0.1 \mathrm{~g})$ for an hour to obtain a clear solution. Light blue crystals of the metal complex were formed by the slow evaporation of solvent after $2 \mathrm{w}$. The compound was filtered and dried in a vacuum (fig. 2).

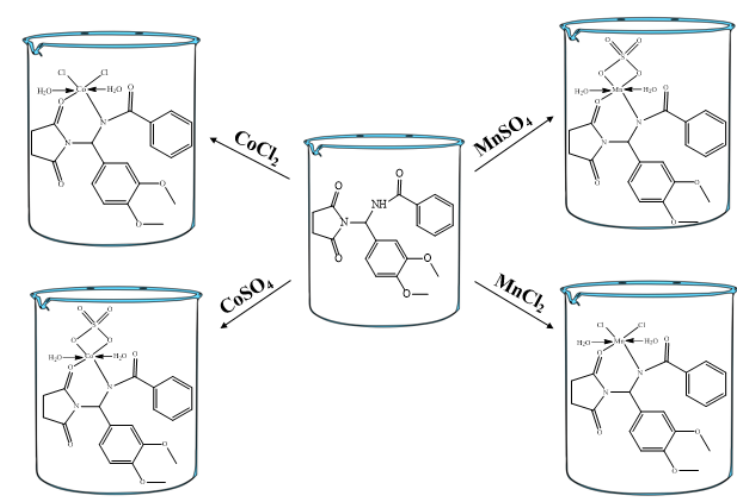

Fig. 2: Synthesis of Co and Mn (II) metal complexes of NDB

\section{RESULTS AND DISCUSSION}

\section{Physical measurements}

The physical properties and elemental analysis of the prepared ligand and its metal complexes are described in table 1 and 2 . The structures of the metal complexes were further confirmed by conductivity measurements and magnetic moment determinations. The molar conductance studies reveal that all the complexes are non-electrolytes. The CHNO values are also in agreement with the calculated values.

Table 1: Elemental analysis of the ligand (NDB) and its metal complexes

\begin{tabular}{|c|c|c|c|c|}
\hline \multirow{2}{*}{$\begin{array}{l}\text { Compound } \\
\mathrm{NDB}_{20} \mathrm{H}_{20} \mathrm{~N}_{2} \mathrm{O}_{5}\end{array}$} & \multicolumn{4}{|c|}{ Found (calculated \%) } \\
\hline & $\mathrm{C}$ & $\mathrm{H}$ & $\mathrm{N}$ & 0 \\
\hline & $65.16(65.21)$ & $5.42(5.47)$ & $7.59(7.60)$ & $21.69(21.72)$ \\
\hline $\mathrm{MnSO}_{4} \cdot 2 \mathrm{H}_{2} \mathrm{O} . \mathrm{NDB}$ & $44.23(44.29)$ & $4.1(4.6)$ & $4.88(4.92)$ & $30.89(30.91)$ \\
\hline $\mathrm{C}_{21} \mathrm{H}_{26} \mathrm{MnN}_{2} \mathrm{O}_{11} \mathrm{~S}$ & & & & \\
\hline $\mathrm{MnCl}_{2} \cdot 2 \mathrm{H}_{2} \mathrm{O} . \mathrm{NDB}$ & $46.31(46.34)$ & $4.80(4.81)$ & $5.13(5.15)$ & $20.56(20.58)$ \\
\hline $\mathrm{C}_{21} \mathrm{H}_{26} \mathrm{Cl}_{2} \mathrm{MnN}_{2} \mathrm{O}_{7}$ & & & & \\
\hline $\mathrm{CoSO}_{4} .2 \mathrm{H}_{2} \mathrm{O} . \mathrm{NDB}$ & $43.94(43.98)$ & $4.76(4.78)$ & $4.88(4.89)$ & $30.65(30.69)$ \\
\hline $\mathrm{C}_{21} \mathrm{H}_{26} \mathrm{CoN}_{2} \mathrm{O}_{11} \mathrm{~S}$ & & & & \\
\hline $\mathrm{CoCl}_{2} \cdot 2 \mathrm{H}_{2} \mathrm{O}$. NDB & $45.97(46.00)$ & $4.74(4.78)$ & $5.09(5.11)$ & $20.40(20.43)$ \\
\hline
\end{tabular}

Table 2: Molar conductance and magnetic susceptibility

\begin{tabular}{|c|c|c|}
\hline Compound & Molar conductance $\Lambda \mathrm{m}\left(\mathrm{mhocm}^{2} / \mathrm{mol}\right)$ & Magnetic susceptibility $\mu \mathrm{eff}$ (B. M) \\
\hline NDB & - & - \\
\hline $\mathrm{MnSO}_{4} \cdot 2 \mathrm{H}_{2} \mathrm{O} . \mathrm{NDB}$ & 26 & 4.73 \\
\hline $\mathrm{MnCl}_{2} .2 \mathrm{H}_{2} \mathrm{O} . \mathrm{NDB}$ & 30 & 5.20 \\
\hline $\mathrm{CoSO}_{4} \cdot 2 \mathrm{H}_{2} \mathrm{O} . \mathrm{NDB}$ & 28 & 4.28 \\
\hline $\mathrm{CoCl}_{2} .2 \mathrm{H}_{2} \mathrm{O} . \mathrm{NDB}$ & 31 & 4.90 \\
\hline
\end{tabular}




\section{UV-visible spectroscopic measurements}

Absorbance in the UV-Visible region was recorded in DMF solution using the UV-Visible spectrometer (table 3).

Manganous sulphate complex has given the sharp absorption peaks at $17981 \mathrm{~cm}^{-1}, 24865 \mathrm{~cm}^{-1}$, and $28000 \mathrm{~cm}^{-1}$ due to ${ }^{6} \mathrm{~A}_{1 \mathrm{~g}} \rightarrow{ }^{4} \mathrm{~T}_{1 \mathrm{~g}}$ ${ }^{6} \mathrm{~A}_{1 \mathrm{~g}} \rightarrow{ }^{4} \mathrm{E}_{\mathrm{g}}+{ }^{4} \mathrm{~A}_{1 \mathrm{~g}}$ and ${ }^{6} \mathrm{~A}_{1 \mathrm{~g}} \rightarrow{ }^{4} \mathrm{~T}_{2 \mathrm{~g}}$ transitions, respectively. This type of absorption confirms the octahedral geometry, which is further evident by the magnetic moment value at 4.73B. M [12]

Manganous chloride complex has shown four absorption bands at $18100 \mathrm{~cm}^{-1}, 24860 \mathrm{~cm}^{-1}, 29156 \mathrm{~cm}^{-1}$, and $31196 \mathrm{~cm}^{-1}$ for the transitions ${ }^{6} \mathrm{~A}_{1 \mathrm{~g}} \rightarrow{ }^{4} \mathrm{~T}_{1 \mathrm{~g}},{ }^{6} \mathrm{~A}_{1 \mathrm{~g}} \rightarrow{ }^{4} \mathrm{E}_{2 \mathrm{~g}},{ }^{6} \mathrm{~A}_{1 \mathrm{~g}} \rightarrow{ }^{4} \mathrm{E}_{1 \mathrm{~g}}$, and charge transfer. The magnetic moment data was found to be 5.20, suggestive of high spin octahedral geometry [13].

For Cobalt sulphate complex, the spectra appeared at $6910 \mathrm{~cm}^{-1}$, $15010 \mathrm{~cm}^{-1}, \quad 18523 \mathrm{~cm}^{-1}$ and $24100 \mathrm{~cm}^{-1}$ due to ${ }^{4} \mathrm{~A}_{2} \rightarrow{ }^{4} \mathrm{~T}_{2},{ }^{4} \mathrm{~A}_{2} \rightarrow{ }^{4} \mathrm{~T}_{1},{ }^{4} \mathrm{~T}_{1 \mathrm{~g}} \rightarrow{ }^{4} \mathrm{~T}_{2} \mathrm{~g}$, and $\mathrm{CT}$ respectively. The magnetic moment data was found as 4.28 in agreement with octahedral geometry [14].

Cobalt chloride complex registered four peaks corresponding to ${ }^{4} \mathrm{~T}_{1 \mathrm{~g}} \rightarrow{ }^{4} \mathrm{~T}_{2 \mathrm{~g}},{ }^{4} \mathrm{~T}_{1 \mathrm{~g}} \rightarrow{ }^{4} \mathrm{~A}_{2 \mathrm{~g}},{ }^{4} \mathrm{~A}_{1} \mathrm{~g} \rightarrow{ }^{4} \mathrm{~T}_{1 \mathrm{~g}}$, and charge transfer transition at $6698 \mathrm{~cm}^{-1}, 14300 \mathrm{~cm}^{-1}, 18736 \mathrm{~cm}^{-1}$ and $29075 \mathrm{~cm}^{-1}$. The magnetic moment value was obtained as 4.90 supporting octahedral geometry [15].

Table 3: UV-Visible spectral analysis

\begin{tabular}{|c|c|c|c|}
\hline Compound & $\lambda_{\max }\left(\mathrm{cm}^{-1}\right)$ & Transition assignment & Geometry \\
\hline \multirow[t]{3}{*}{$\mathrm{MnSO}_{4} \cdot 2 \mathrm{H}_{2} \mathrm{O} . \mathrm{NDB}$} & 17981 & ${ }^{6} \mathrm{~A}_{1 \mathrm{~g}} \rightarrow{ }^{4} \mathrm{~T}_{1 \mathrm{~g}}$ & Octahedral \\
\hline & 24865 & ${ }^{6} \mathrm{~A}_{1 \mathrm{~g}} \rightarrow{ }^{4} \mathrm{E}_{\mathrm{g}}+{ }^{4} \mathrm{~A}_{1 \mathrm{~g}}$ & \\
\hline & 28000 & ${ }^{6} \mathrm{~A}_{1 \mathrm{~g}} \rightarrow{ }^{4} \mathrm{~T}_{2 \mathrm{~g}}$ & \\
\hline \multirow[t]{4}{*}{$\mathrm{MnCl}_{2} \cdot 2 \mathrm{H}_{2} \mathrm{O} . \mathrm{NDB}$} & 18100 & ${ }^{6} \mathrm{~A}_{1 \mathrm{~g}} \rightarrow{ }^{4} \mathrm{~T}_{1 \mathrm{~g}}$ & High spin Octahedral \\
\hline & 24860 & ${ }^{6} \mathrm{~A}_{1 \mathrm{~g}} \rightarrow{ }^{4} \mathrm{E}_{2 \mathrm{~g}}$ & \\
\hline & 29156 & ${ }^{6} \mathrm{~A}_{1 \mathrm{~g}} \rightarrow{ }^{4} \mathrm{E}_{1 \mathrm{~g}}$ & \\
\hline & 31196 & $\mathrm{CT}$ & \\
\hline \multirow[t]{4}{*}{$\mathrm{CoSO}_{4} \cdot 2 \mathrm{H}_{2} \mathrm{O} . \mathrm{NDB}$} & 6910 & ${ }^{4} \mathrm{~A}_{2} \rightarrow{ }^{4} \mathrm{~T}_{2}$ & Octahedral \\
\hline & 15010 & ${ }^{4} \mathrm{~A}_{2} \rightarrow{ }^{4} \mathrm{~T}_{1}$ & \\
\hline & 18523 & ${ }^{4} \mathrm{~T}_{1 \mathrm{~g}} \rightarrow{ }^{4} \mathrm{~T}_{2 \mathrm{~g}}$ & \\
\hline & 24100 & $\mathrm{CT}$ & \\
\hline \multirow[t]{4}{*}{$\mathrm{CoCl}_{2} \cdot 2 \mathrm{H}_{2} \mathrm{O}$. NDB } & 6998 & ${ }^{4} \mathrm{~T}_{1 \mathrm{~g}} \rightarrow{ }^{4} \mathrm{~T}_{2 \mathrm{~g}}$ & Octahedral \\
\hline & 14300 & ${ }^{4} \mathrm{~T}_{1 \mathrm{~g}} \rightarrow{ }^{4} \mathrm{~A}_{2 \mathrm{~g}}$ & \\
\hline & 18736 & ${ }^{4} \mathrm{~A}_{1} \mathrm{~g} \rightarrow{ }^{4} \mathrm{~T}_{1 \mathrm{~g}}$ & \\
\hline & 29075 & $\mathrm{CT}$ & \\
\hline
\end{tabular}

FT-IR spectral analysis of the ligand NDB and its metal complexes

For finding out the possible coordination sites, the IR spectra of the ligand and metal complexes were recorded in FT-IR spectrometer in the $\mathrm{KBr}$ phase. Characteristic vibrational bands of the ligand and its metal complexes and their assignments are given in table 4 . The IR spectrum of the free ligand exhibited a strong band at $1680 \mathrm{~cm}-1$ for $v(C=0)$ stretching of the succinimide ring [16]. A band at $3302 \mathrm{~cm}-1$ corresponds to the stretching vibration of the $(\mathrm{N}-\mathrm{H})$ bond. In metal complexes, there is a shift of $v(\mathrm{C}=0)$ vibration to lower frequency range suggesting the coordination of carbonyl group of succinimide ring with the metal atoms in the complexes. The N-C-N stretching frequency of the ligand at $1400 \mathrm{~cm}-1$ was lowered in the metal complexes confirming the involvement of the nitrogen atom of benzamide with the metal atoms. This is further supported by the appearance of new bands around $400-420 \mathrm{~cm}^{-1}$ in the far IR region for the coordination of metal-nitrogen and metal-oxygen [17].

Table 4: FT-IR frequency bands of the ligand NDB and its metal complexes

\begin{tabular}{|c|c|c|c|c|c|}
\hline Compound & $\mathbf{v}_{\mathrm{NH}}$ & $V_{C}=0$ & N-C-N & M-N & M-0 \\
\hline NDB & 3302 & 1680 & 1400 & - & - \\
\hline $\mathrm{MnSO}_{4} \cdot 2 \mathrm{H}_{2} \mathrm{O} . \mathrm{NDB}$ & 3284 & 1674 & 1411 & 420 & 413 \\
\hline $\mathrm{MnCl}_{2} \cdot 2 \mathrm{H}_{2} \mathrm{O} . \mathrm{NDB}$ & 3297 & 1668 & 1395 & 401 & 425 \\
\hline $\mathrm{CoSO}_{4} \cdot 2 \mathrm{H}_{2} \mathrm{O} . \mathrm{NDB}$ & 3185 & 1673 & 1407 & 415 & 412 \\
\hline $\mathrm{CoCl}_{2} .2 \mathrm{H}_{2} \mathrm{O}$. NDB & 3267 & 1672 & 1410 & 405 & 418 \\
\hline
\end{tabular}

\section{H NMR spectral data of NDB}

The ${ }^{1} \mathrm{H}$ NMR spectra of NDB shows a singlet at $\delta 2.57$ due to methylene proton. The doublet at $\delta 3.35 \delta$ is assigned to methoxy proton. A multiplet between 6.26-6.88 $\delta$ is assigned for aromatic protons. The singlet for one proton at $\delta 8.48$ is assigned to- $\mathrm{NH}$ proton.

\section{${ }^{13} \mathrm{C}$ NMR spectral data of NDB}

The number of signals of sharp peaks represents the number of carbons of the ligand, which are not chemically equivalent. ${ }^{13} \mathrm{C}$ NMR$40.0,60.36,116.00,119.23,120.32,126.73,131.04,139.62,159.62$, $172.66,179.35$

\section{Mass spectral data of NDB}

The molecular formula of NDB based on elemental analysis is $\mathrm{C}_{20} \mathrm{H}_{20} \mathrm{~N}_{2} \mathrm{O}_{5}$. Observed molecular mass by LC-MS spectrometer is 367.25 , which is in closer value with the calculated value 368.14 .

\section{Anti-fungal activity}

Mannich bases and their metal complexes have potent antimicrobial activities [19]. The anti-fungal property of the synthesized Mannich base and its metal complexes were examined against $\mathrm{A}$. niger and C. albicans. The anti-fungal activity of each compound was compared with the standard drug Fluconazole. The inhibition zones were measured at the concentration of $100 \mu \mathrm{g} / \mathrm{ml}$ and $400 \mu \mathrm{g} / \mathrm{ml}$. at the concentration of $400 \mu \mathrm{g} / \mathrm{ml}$, all the metal complexes have shown better anti-fungal activity against the selected microorganisms. The percentage inhibition for fungi is calculated after five days using the formula.

Percentage of inhibition $=100(\mathrm{X}-\mathrm{Y}) / \mathrm{X}(\mathrm{X}$-Area of the colony in control plate; $\mathrm{Y}=$ Area of the colony in test plate).

\section{DNA binding and cleavage activities}

The interaction of the synthesized Co (II)sulphate complex with DNA is monitored with the help of absorption titrations. At fixed 
concentrations of the complex, the interaction with DNA (pBR322 and calf thymus) was investigated using UV absorption spectra. There is a redshift (hypochromic effect) in the absorption spectra for the metal complex, which is usually characteristic for non-covalent intercalative binding of the compound to DNA helix, which is because of effective stacking interaction of aromatic chromophore of the compound with the base pairs of DNA [20]. Fig. 3 represents the absorption spectra of the complex in the absence and presence of increasing amounts of DNA. In the UV region, a strong absorption peak was observed due to the metal complex. The gradual addition of DNA resulted in hypochromism and bathochromic shift in UV spectra [21]. The bathochromism result is due to the decrease in the energy of $\pi-\pi^{*}$ transition. Here, the $\pi$ orbital of the DNA base pair might have been coupled with $\pi-\pi^{*}$ orbital of the intercalated ligand.

Table 5: Antifungal activity of NDB and its metal complexes

\begin{tabular}{|c|c|c|c|c|}
\hline \multirow[t]{2}{*}{ Compound } & \multicolumn{2}{|c|}{ A. niger } & \multicolumn{2}{|c|}{ C. albicans } \\
\hline & \multicolumn{2}{|c|}{$100 \mu \mathrm{g} / \mathrm{ml} 400 \mu \mathrm{g} / \mathrm{ml}$} & \multicolumn{2}{|c|}{$100 \mu \mathrm{g} / \mathrm{ml} 400 \mu \mathrm{g} / \mathrm{ml}$} \\
\hline NDB (1AF) & 12 & 20 & 11 & 19 \\
\hline $\mathrm{MnSO}_{4} \cdot 2 \mathrm{H}_{2} \mathrm{O} . \mathrm{NDB}(2 \mathrm{AF})$ & 14 & 23 & 15 & 24 \\
\hline $\mathrm{MnCl}_{2 .} 2 \mathrm{H}_{2} \mathrm{O} . \mathrm{NDB}(3 \mathrm{AF})$ & 16 & 22 & 14 & 20 \\
\hline $\mathrm{CoSO}_{4} \cdot 2 \mathrm{H}_{2} \mathrm{O} . \mathrm{NDB}(4 \mathrm{AF})$ & 13 & 19 & 12 & 19 \\
\hline $\mathrm{CoCl}_{2} \cdot 2 \mathrm{H}_{2} \mathrm{O} . \mathrm{NDB}(5 \mathrm{AF})$ & 18 & 24 & 18 & 23 \\
\hline
\end{tabular}

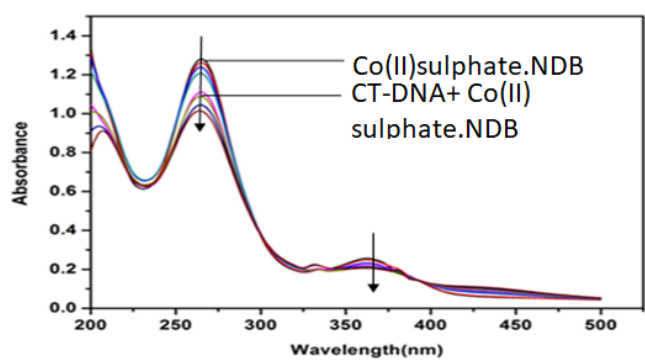

Fig. 3: Absorption spectra of the cobalt (II)sulphate complex of NDB in the absence and presence of increasing amounts of CT-

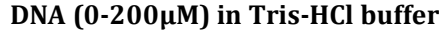

\section{Agarose gel electrophoresis}

The electrophoresis of the samples $\mathrm{MnSO}_{4} \cdot 2 \mathrm{H}_{2} \mathrm{O}$. NDB, $\mathrm{MnCl}_{2} .2 \mathrm{H}_{2} \mathrm{O}$. NDB, $\mathrm{CoSO}_{4} \cdot 2 \mathrm{H}_{2} \mathrm{O}$. NDB was done according to the following procedure: $200 \mathrm{mg}$ of agarose gel is weighed and dissolved in $25 \mathrm{ml}$ of TAE buffer (4.84g Tris base, pH 8, 0.5M EDTA/1lr) by boiling. When the gel attained approximately $55^{\circ} \mathrm{C}$, it is poured into the gel cassette fitted with the comb and solidified. The comb was carefully removed, and the gel is placed in the electrophoresis chamber flooded with TAE buffer. DNA sample is then loaded carefully into the wells, along with standard DNA marker and 50V of electricity is passed for around $45 \mathrm{~min}$. Then the gel is removed carefully, and the bands are observed under UV transilluminator. From the photocleavage studies, it is understood that Mn (II) metal complexes have shown complete cleavage of DNA [22]. Co (II) sulphate complex at $30 \mu \mathrm{M}$ concentration has cleaved supercoiled (Form I) DNA, whereas the linear (Form II) is clearly seen (fig. 4). But at $50 \mu \mathrm{M}$

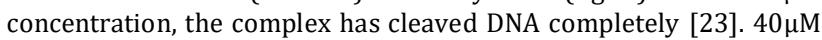
$\mathrm{H}_{2} \mathrm{O}_{2}$ alone has not displayed any activity over DNA.

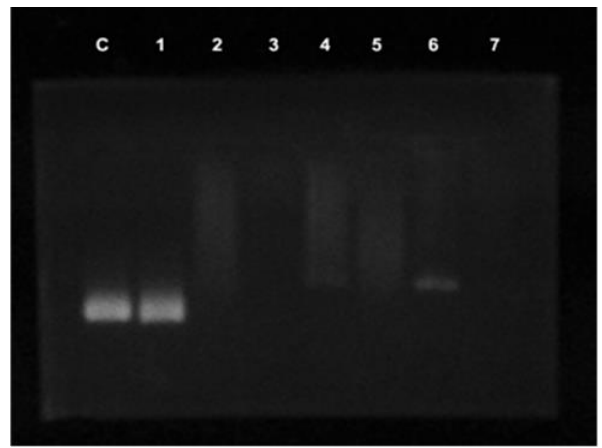

Fig. 4: C-Control DNA (untreated sample); 1-DNA with $40 \mu \mathrm{M}$

$\mathrm{H}_{2} \mathrm{O}_{2} ; 2$ and3- $\mathrm{MnSO}_{4} .2 \mathrm{H}_{2} \mathrm{O}$. NDB at 30 and $50 \mu \mathrm{M} ; 4$ and 5$\mathrm{MnCl}_{2} 2 \mathrm{H}_{2} \mathrm{O}$. NDB at 30 and $50 \mu \mathrm{M} ; 6$ and $7-\mathrm{CoSO}_{4} .2 \mathrm{H}_{2} \mathrm{O}$. NDB at 30 and $50 \mu \mathrm{M}$, respectively

\section{CONCLUSION}

In this article, a new Mannich base and its coordination complexes with transition metals $\mathrm{Mn}$ and Co have been synthesized and characterized based on spectral and analytical data. The Mannich base coordinated with the metal atom through the nitrogen of benzamide and oxygen of succinimide. All the complexes exhibit octahedral geometry. The ligand and the metal complexes have shown good antifungal activity. The Co (II) sulphate metal complex has shown marked DNA binding ability. The nuclease activity of the synthesized Co (II) complex could induce the cleavage of supercoiled DNA effectively to linear form in the presence of $\mathrm{H}_{2} \mathrm{O}_{2}$ as the oxidizing agent.

\section{ACKNOWLEDGEMENT}

The author wishes to thank Madras University for DNA binding studies, Biogenics Hubli for DNA cleavage studies and IIISM, SRMIST for spectral studies.

\section{FUNDING}

Nil

\section{AUTHORS CONTRIBUTIONS}

All the authors have contributed equally.

\section{CONFLICTS OF INTERESTS}

The author declares no competing interest exists.

\section{REFERENCES}

1. Sivakumar KK, Rajasekaran A, Senthilkumar P, Wattamwar PP Conventional and microwave-assisted synthesis of pyrazolone Mannich bases possessing anti-inflammatory, analgesic, ulcerogenic effect and antimicrobial properties. Bioorg Med Chem Lett. 2014;24(13):2940-4. doi: 10.1016/j.bmcl.2014.04.067, PMID 24835630.

2. Vijayanandhi M, Verma AK, Sujatha R, Kamal Raj R. Synthesis, and characterization of novel Mannich base of benzimidazole derivatives for antibacterial and antifungal activity. Int J Pharm Pharm Sci. 2013;5(2):295-7.

3. Balakrishnan A, Sankar A, Nandhini V. Synthesis, Structure and antimicrobial studies of Mannich base N(dicyclohexylamino)(phenyl)methylbenzamide and its metal complexes. Int J Chem Physiol Sci. 2018;7(2):1-7.

4. Chakkaravarthi K, Gokulakrishnan K, Suman T, Tamilvendan D. Synthesis, spectral, antimicrobial and antioxidant studies of diamide Mannich base derivatives. Int J Pharm Pharm Sci. 2015;6(1):492-5.

5. More MS, Pawal SB, Lolage SR, Chavan. Synthesis, structural characterization, luminescence and optical studies of $\mathrm{Ni}(\mathrm{II})$ and Zn(II) complexes containing salophen ligand. J Mol Struct. 2017;11(28):419-27.

6. Madhu G, Jayaveera KN, Ravindra Nath LK, Santhosh Kumar B, Nagarjuna Reddy P. Synthesis and structure-activity relationship of new antibacterial active multisubstituted quinoline azetidinone Mannich bases. Der Pharm Chem. 2012;4(3):1033-40. 
7. Pahontu E, Julea F, Rosu T, Purcarea V, Chumakov Y, Petrenco $\mathrm{P}$, Gulea A. Antibacterial, antifungal and in vitro antileukaemia activity of metal complexes with thiosemicarbazones. J Cell Mol Med. 2015;19(4):865-78. doi: 10.1111/jcmm.12508.

8. Rehman Mu. Metal-based antimicrobial agents: Synthesis, characterization and biological studies of mannich base derivatives of benzimidazole and their metal complexes. SJC. 2013;1(5). doi: 10.11648/j.sjc.20130105.12

9. Arundhati M, Dipak C, Mithun R. Synthesis and antimalarial activity of lawsone Mannich base derivatives. Ind J Pharm Educ Res. 2018;52(3):472-9. doi: 10.5530/ijper.52.3.55.

10. Itzel L, Nery Flores L-LSD, Saenze Galindo A. Facile synthesis of amino naphthaquinone mannich bases by nano catalytic multicomponent reaction. Syn Commun. 2017;47(23):2247-53.

11. Zayed EM, Zayed MA, El-Desawy M. Preparation and structure investigation of novel Schiff bases and their biological activities. Mol Biomol Spec. 2015;134:155-64.

12. Raju KR, Guru Prasad A, Kumar B, Rao L, Ravindranath KR. Synthesis and medicinal evaluation of Mannich bases carrying azetidone moiety. J Clin Anal Med. 2014;2:1-5.

13. Malhotra M, Sharma R, Sanduja M, Kumar R, Jain J, Deep A. Synthesis, characterization and evaluation of mannich bases as potent antifungal and hydrogen peroxide scavenging agents. Acta Pol Pharm. 2012;69(2):355-61. PMID 22568052.

14. Sevgi F, Bagkesici U, Kursunlu AN, Guler E. Fe (III), Co(II), $\mathrm{Ni}(\mathrm{II}), \mathrm{Cu}(\mathrm{II})$ and $\mathrm{Zn}(\mathrm{II})$ complexes of schiff bases based-on glycine and phenylalanine: Synthesis, magnetic/thermal properties and antimicrobial activity. J Mol Struct. 2018;1154:256-60. doi: 10.1016/j.molstruc.2017.10.052.

15. Manjula B, Arul S. Preparation, characterization, antimicrobial activities and DNA cleavage studies of schiff base complexes derived from 4-aminoantipyrine. Asian J Biochem Pharm Res. 2013;1:168-78

16. Malhotra M, Arora M, Samad A, Sahu K, Phogat P, Deep A. Synthesis and evaluation of some novel derivatives of 2 - propoxybenzylidene isonicotinohydrazide for their potential antimicrobial activity. J Serb Chem Soc. 2012;77(5):589-97. doi: 10.2298/JSC110310170M.

17. Aditi A, Jahav V, Vaishali P, Dhanwe Pawan K, Khanna. Synthesis of novel $\mathrm{Zn}(\mathrm{II})$ and $\mathrm{Cd}(\mathrm{II})$ complexes of semicarbazones and their utility as precursors for respective metal selenide quantum dots. Polyhed. 2017;123:99-110.

18. Kailas KH, Sheetal JP, Anita PP, Apporva HP. Four synthesis methods of Schiff base ligands and preparation of their metal complexes with ir and antimicrobial investigation. World J Pharm Pharm Sci. 2016;5(2):1055-63.

19. da Silva GB, Neves AP, Vargas MD, Marinho-Filho JDB, Costa Lotufo LV. New insights into 3-(aminomethyl) naphthoquinones: evaluation of cytotoxicity, electrochemical behavior and search for structure-activity correlation. Bioorg Med Chem Lett. 2016;26(15):3537-42. doi: 10.1016/ j.bmcl.2016.06.027.

20. Olar R, Calu L, Badea M. Thermal behavior of some biologically active species based on complexes with triazolopyrimidine pharmacophore. J Ther Anal Calori. 2017;127(1):472-9.

21. Golmakaniyoon, Sima, Askar, Vahid Reza A, Khalil, Zarghi, Afshin. Ghodsi and Razieh. Synthesis, characterization and in vitro-evaluation of novel naphthaquinone derivatives and related amines: identification of new cancer leads, Ira. J Pharm Res. 2019;18(1):16-29.

22. Bharty MK, Paswan S, Dani RK. Polymeric Cd(II), trinuclear and mononuclear $\mathrm{Ni}(\mathrm{II})$ complexes of 5-methyl-4-phenyl-1,2,4triazole-3-thione: Synthesis, structural characterization, thermal behavior, fluorescence properties and antibacterial activity. J Mol Struct. 2017;1130:181-93.

23. Najlaa S, Al-Radadi EM, Zayed GG, Mohamed, Hayam A, Abd El Salam. Synthesis, spectroscopic characterization, molecular docking and evaluation of the antibacterial potential of transition metal complexes using triazole chelating ligand. J Chem. 2020;2(2):1-12. 